\title{
NOVO CÓDIGO DE TRÂNSITO — OS MUNICÍPIOS E O POLICIAMENTO
}

\section{DIÓGENES GASPARINI*}

1. Introdução. - 2. Competência legislativa municipal em matéria de trânsito. - 3. Interesse local ou peculiar interesse dos Municipios. - 4. Ordem Pública: valor nacional que suplanta o interesse local. -5 . Polícia de ordem pública ou polícia administrativa geral e polícia administrativa especial. - 6. Policia de ordem pública e sua polícia de trânsito, como atividade jurídica do Estado. - 7. Poder de polícia de trânsito: capacidade indelegável à pessoa jurídica de direito privado. 8. Vinculação da receita proveniente das multas de trânsito. - 9. Policiamento ostensivo de trânsito e fiscalização de trânsito. - 10. Competência da Polícia Militar para exercer o policiamento ostensivo de trânsito. - 11. Abordagem de veículo e registro de acidente de trânsito. 12. Órgãos de transito. - 13. A interrup̧̧ão da via pública e o direito de reunião.

\section{Introdução}

A Lei federal $\mathrm{n}^{\mathbf{2}}$ 9.503, de 23 de setembro de 1997, instituiu o Código de Trânsito Brasileiro, em substituição ao Código Nacional de Trânsito, que muitos achavam inadequado para fazer frente à realidade atual do trânsito no país.

A principal queixa consistia em atribuir à legislação a responsabilidade pelos nossos altos índices de acidentes - verdadeira guerra a ceifar milhares de vidas e a deixar outro tanto de brasileiros mutilados.

Sempre entendemos que o enfoque excessivamente legalista constituía um equívoco, pois todas as pessoas que tratam de trânsito sabem que essa atividade sustenta-se no seguinte tripé: legislação ou esforço legal, engenharia e educação, sendo esta, na nossa opinião, a principal.

O Código Nacional de Trânsito era uma norma sistemicamente correta, que

* Advogado, Mestre e Doutor pela PUC/SP, Professor Titular de Direito Administrativo e Diretor da Faculdade de Direito de São Bernardo do Campo.

R. Dir. Adm.,

Rio de Janeiro, 212: 175-194,

abr./jun. 1998 
necessitava ajustes pontuais para a devida atualização. Ao invés disso, optou-se pela adoção de um novo Código que sofreu dezenas de vetos cujo alcance só o tempo e a prática demonstrarão.

Neste trabalho, que não tem a pretensão de esgotar o assunto, examinamos, de forma técnica, os principais temas ligados à atuação da Administração Pública, nas três esferas de governo, procurando na exegese sistêmica dirimir algumas dúvidas que a nova Lei pode suscitar.

\section{Competência legislativa municipal em matéria de trânsito}

No que respeita à competência legislativa do Município, em matéria de trânsito, podemos afirmar, seguramente, não se tratar de matéria de interesse local, haja vista ter sido reservada expressamente e de forma privativa, à União, consoante dispõe o art. 22, inc. XI, da Constituição da República, quando estabelece:

“Art. 22. Compete privativamente à União legislar sobre:

XI — trânsito e transporte;"

Analisando essa norma constitucional, o Corpo Técnico jurídico da Fundação Prefeito Faria Lima - CEPAM, Órgão hoje vinculado à Secretaria de Planejamento $e$ Gestão do Estado de São Paulo, no livro Breves Anotações à Constituição de 1988, S. Paulo, CEPAM, Atlas, 1990, p. 120, manifestou-se da seguinte forma:

"São de ordem legislativa todos os assuntos enumerados neste artigo e que abrangem matérias sobre as quais somente a União poderá legislar. Não poderão os Estados, Municípios e Distrito Federal legislar sobre quaisquer dessas matérias, sob pena de invadir competência exclusiva da União".

Desse mesmo entender é a inteligência do professor José Afonso da Silva, em seu Curso de Direito Constitucional Positivo, $9^{\mathrm{a}}$ ed., revista e ampliada de acordo com a nova Constituição, 4a tiragem, Malheiros, S. Paulo, 1994, p. 439, que ao dissertar sobre a competência legislativa da União assevera:

"Toda a matéria de competência da União é suscetivel de regulamentação mediante lei (ressalvado o disposto nos arts. 49, 51 e 52), conforme dispõe o art. 48 da Constituição. Mas os arts. 22 e 24 especificam seu campo de competência legislativa, que consideramos em dois grupos: a exclusiva $e$ a concorrente.

I - competência legislativa exclusiva sobre:

1) Direito Administrativo:...

j) trânsito e transporte;" (grifos originais e nossos).

Destarte, não é possível fugir da norma constitucional, e também da doutrina pacífica que versa sobre o assunto, para permitir ao Município ou ao Estado legislar onde essa competência somente cabe à União. E mais, o Poder Público está atrelado ao mandamento legal não podendo dele se afastar, sob pena de responsabilização do agente público, nas esferas administrativas, penal e civil

O novo Código de Trânsito não divergiu dessa linha de pensamento e agrupou, no Conselho Nacional de Trânsito - CONTRAN, Órgão da União (art. 10), todas 
as competências normativas suplementares à lei federal (art. 12), além de funções de coordenação do Sistema Nacional de Trânsito.

O Município, portanto, não dispõe de nenhuma competência legislativa em matérias que não atinem com o interesse local, como trânsito, transporte coletivo intermunicipal, serviço postal, dentre outras, mesmo quando realizadas no seu território. Pelos mesmos motivos, não lhe cabe legislar e, menos ainda, prestar serviços de policiamento ostensivo de trânsito, competência esta das Polícias Militares, como adiante veremos.

Com efeito, nas responsabilidades legislativas privativas da União, só se admite, excepcionalmente, a atuação de Estados e Municípios, mediante lei complementar e, mesmo assim, sobre questões específicas, conforme faculta o parágrafo único, do art. 22, do Estatuto Supremo.

As competências comuns da União, dos Estados, do Distrito Federal e dos Municípios estão elencadas no art. 23, da Carta Política Federal, cabendo-lhes, consoante os incs. I e XII, a título de exemplo: "zelar pela guarda da Constituição, das leis e das instituições democráticas e conservar o patrimônio público" e "estabelecer e implantar política de educação para a segurança do trânsito", desde que estejam instituídas, em lei complementar, as devidas regras de cooperação conforme estabelece o parágrafo único, do referido artigo, senão vejamos:

"Parágrafo único. Lei complementar fixará normas para a cooperação entre a Uniāo e os Estados, o Distrito Federal e os Municipios, tendo em vista o equilíbrio do desenvolvimento e do bem-estar em âmbito nacional". (grifo nosso).

Note-se que a Lei $\mathrm{n}^{2}$ 9.503, de 23 de setembro de 1997, que institui o novo Código de Trânsito Brasileiro, é lei ordinária, portanto imprópria para estabelecer as aludidas regras.

Por fim, no art. 24 estão as competências legislativas concorrentes da União, dos Estados e, do Distrito Federal. $\mathrm{O} \S 1^{\mathrm{Q}}$ prescreve que nesse particular cabe à União estabelecer apenas normas gerais, enquanto o $\S 2^{9}$ estatui que a competência da União não exclui a competência suplementar dos Estados e, o $\S 3^{\circ}$, por sua vez, estabelece que, inexistindo normas gerais, os Estados exercerão a competência legislativa plena. No caso que estamos examinando, há legislação federal e estadual, que foram recepcionadas pela Constituição da República, versando sobre o policiamento ostensivo de trânsito, como mais adiante restará demonstrado.

\section{Interesse local ou peculiar interesse dos Municípios}

Inequivocamente, interesse local é igual a peculiar interesse. Aos Municípios, nos termos do inc. I, do art. 30, da Lei Maior, cabe dispor sobre assuntos de interesse local:

"Art. 30. Compete aos Municipios:

I - legislar sobre assuntos de interesse local;"

O Constituinte de 1988 preferiu substituir a tradicional cláusula do peculiar interesse, configurada nas Constituições anteriores, pelo interesse local, sem, contudo, inovar no seu conteúdo. A novidade ocorreu, tão-só, na locução. Assim, 
interesse local não é outra coisa senão aquele que prepondera, que sobressai, quando confrontado com o do Estado-membro ou com o da União. De sorte que ainda vale a precisa lição do saudoso professor Hely Lopes Meirelles, em seu Direito Municipal Brasileiro, 6 ed., atualizada por Izabel Camargo Lopes Monteiro e Yara Darcy Police Monteiro, 1993, Malheiros, p. 98:

"Interesse local não é interesse exclusivo do Município; não é interesse privativo da localidade; não é interesse único dos municipios. Se se exigisse essa exclusividade, essa privatividade, essa unicidade, bem reduzido ficaria o âmbito da Administração local, aniquilando-se a autonomia de que faz praça a Constituição. Mesmo porque não há interesse municipal que não o seja reflexamente da União e do Estado-membro, como, também, não há interesse regional ou nacional que não ressoe nos Municípios, como partes integrantes da Federação brasileira. $O$ que define e caracteriza o 'interesse local', inscrito como dogma constitucional, é a predominância do interesse do Município sobre o do Estado ou da União" (grifos originais).

Mais uma vez, o Corpo Técnico-jurídico da Fundação Prefeito Faria Lima CEPAM, na obra acima citada, às pp. 144 e 145, deixou entrever que a locução interesse local, consignada no art. 30 , inc. I, da Constituição, apenas substituiu a expressão peculiar interesse grafada nas Constituições anteriores, pois tratou aquela tal qual tratava esta.

No mesmo sentido, manifestou-se o ilustre constitucionalista Michel Temer, hoje Deputado Federal e Presidente da Câmara dos Deputados, assegurando em seu livro Elementos de Direito Constitucional, 13 a ed., revista e atualizada, S. Paulo, Malheiros, 1997, p. 106:

"Doutrina e jurisprudência, ao tempo da Constituição anterior, se pacificaram no dizerem que é de peculiar interesse aquele em que predomina o do Município no confronto com os interesses do Estado e da União. Peculiar interesse significa interesse predominante. Interesse local é expressão idêntica a peculiar interesse" (grifos originais).

É, portanto, de pouca ou de nenhuma valia tentar fundar proposta que insinue competência aos Municípios para legislar sobre matéria de trânsito por considerá-la de interesse local. Seguramente, os serviços de trânsito representam atividade relativa à ordem pública, cuja competência legislativa cabe à União e aos Estados-membros conforme se vê no art. 144, da Lei Maior.

\section{Ordem pública: valor nacional que suplanta o interesse local}

É remansoso o entendimento doutrinário e jurisprudencial que considera a ordem pública um valor nacional, sendo certo que sua guarda a Constituição da República atribui à União (art. 142, in fine) e aos Estados-menbros (art. 144, caput e $\S 5^{5}$ ). Sendo valor nacional, não pode, por conseguinte, ser de interesse local, regulável pelo Município.

Da doutrina, depreende-se com facilidade que o policiamento ostensivo de trânsito e a fiscalização de trânsito, uma de suas formas de atuar para prevenir e 
reprimir as infrações e evitar acidentes, está vinculada à preservação da ordem pública.

O Egrégio Supremo Tribunal Federal, apreciando o Recurso Extraordinário $\mathbf{n}^{\mathbf{9}}$ 14.658, de São Paulo, no dia 03 de julho 1950, relatado pelo eminente Ministro Luiz Gallotti, manifestou-se a esse respeito, unanimemente, da seguinte forma:

“... já estabeleceu, com sua inegável autoridade, que a noção de ordem pública é nacional, não obstante a imprópria denominação que, no caso em que se examinava, deram-lhe de internacional" (grifamos).

Bem por isso, quando o condutor de um veículo desobedece ao semáforo ou faz conversão em local proibido, não fere apenas o interesse local. Está, isto sim, atacando e ferindo um valor nacional, integrante da ordem pública e, portanto, afrontando a segurança pública, que é um dos aspectos da ordem pública, cuja preservação cabe à polícia ostensiva.

Nesse mesmo sentido, vêm os ensinamentos de Diogo de Figueiredo Moreira Neto, oferecidos no Curso de Direito Administrativo, $10^{\mathrm{a}} \mathrm{ed}$., revista, refundida e atualizada pela Constituição de 1988 e pela legislação infraconstitucional posterior, Forense, Rio de Janeiro, 1992, p. 307, quando afirma:

“A esta altura da exposição, convém sublinhar que a segurança de uma sociedade nacional não é o somatório da segurança de cada indivíduo; trata-se de um conceito referido às instituições nacionais, ao Estado e à sua ordem jurídica, enquanto representarem a justa manifestação dos interesses e aspiraçōes nacionais" (grifamos).

De outro lado, o professor José Afonso da Silva, na sua citada obra, Curso de Direito Constitucional Positivo, p. 659, completa:

“ Há, contudo, uma repartição de competências nessa matéria entre a União e os Estados, de tal sorte que o princípio que rege é o de que o problema da segurança pública é de competência e responsabilidade de cada unidade da Federação, tendo em vista as peculiaridades regionais e o fortalecimento do princípio federativo, como, aliás, é da tradição do sistema brasileiro" (grifo original).

Portanto, o serviço de policiamento ostensivo de trânsito, ramo da polícia de preservação de ordem pública, seja nas rodovias estaduais ou municipais ou nas vias urbanas, excetuando-se a competência da União, que é exercida pela Polícia Rodoviária Federal, cabe aos Estados-membros, pois não é predominantemente local, dado destinar-se a coibir a violação da ordem jurídica, a defender a incolumidade do Estado, das pessoas e do patrimônio e a restaurar a normalidade de situações e comportamentos que se opõem a esses valores.

De fato, a quebra da ordem jurídica e os atentados contra o Estado, os indivíduos, o patrimônio e o meio ambiente são comportamentos que repercutem além dos limites do Município, que transcendem suas fronteiras, escapando do interesse predominantemente municipal e determinando, em razão disso, uma outra ordem de competência a cujos integrantes cabe coibi-los.

Clóvis Beznos, Procurador do Estado de São Paulo, a propósito do tema, conclui da seguinte forma o Parecer, Publicado na Revista de Direito Público, vol. 78, p. 180 :

“... mas também pelo fato relevante de que a questão relativa à ordem pública 
diz respeito ao interesse nacional, não se configurando ipso facto em mero interesse peculiar do municipio" (grifo original).

\section{Polícia de ordem pública ou polícia administrativa geral e polícia administrativa especial}

A polícia administrativa, entendem, pacificamente, os administrativistas nacionais e estrangeiros, divide-se em dois grandes ramos: a polícia geral e a polícia especial, ambas subdivididas em espécies.

A polícia administrativa geral é voltada aos aspectos da ordem pública, que são: segurança, tranqüilidade e salubridade, tendo previsão constitucional e legal, permitindo uma maior flexibilidade à Administração Pública por ser mais propícia à atuação discricionária, daí ter o formato de instituição, exigindo preparo e controle adequados de seus quadros, o que vai desde as condições particulares de ingresso, passando por formação, carreira, deveres e direitos, que lhes permitem exercer o poder soberano do Estado, inclusive usando da força para que a lei se sobreponha e a ordem turbada seja, prontamente, restabelecida.

A polícia administrativa especial, por sua vez, não tem por objeto a ordem pública e dilui-se em múltiplos segmentos, conforme os ramos das atividades particulares que lhe cumpre fiscalizar. Sua previsão legal é muito mais estreita que a da polícia de ordem pública e seu formato não é o de instituição, conforme explicam Georges Vedel em seu Droit Administratif, $3^{3}$ ed., Paris, 1964, p. 569/570 e Jean Rivero, na obra homônima Droit Administratif, 3a ed., Paris, 1965, p. 371.

Óbvio está, que não devemos esquecer a distinção existente entre a polícia de ordem pública ou polícia administrativa geral e a polícia administrativa especial, pois na primeira enquadram-se dentre outras espécies, a polícia ostensiva de trânsito, tutelando o direito de ir e vir, enquanto que na segunda impõe-se restrições ao uso e gozo da propriedade, à liberdade de comércio, da indústria, do uso e ocupação do solo e de outras iniciativas dos particulares, onde o Estado, necessariamente, impõe limitações. Logicamente, esta não se confundirá com a polícia administrativa geral, seja na ação preventiva ou mesmo na repressiva.

6. Polícia de ordem pública e sua polícia de trânsito, como atividade jurídica do Estado

Para a preservação da ordem pública atuará a polícia administrativa geral, sendo um dos seus ramos de atividade o policiamento ostensivo de trânsito. A polícia de ordem pública, em razão da gravidade dos seus objetivos, figura entre as atividades jurídicas do Estado, ou na expressão mais em moda, atividade típica de Estado, por isso exclusiva do Estado, como nos ensina Cardozo de Melo Neto em sua apostila A ação social do Estado, S. Paulo, USP, 1917, p.7.

No mesmo sentido está a lição que Mário Masagão nos oferece, em seu Curso 
de Direito Administrativo, 6a ed., S. Paulo, Revista dos Tribunais, 1977, p. 71, quando cuida da descentralização política:

" 172 - $O$ terceiro setor é o da manutenção da ordem interna e da atividade policial. $O$ assunto é da competência dos Estados. Caberá a União operar nesta matéria somente por exceção, quando impotente o Estado federado para manter a ordem em seu território, a situação se enquadre na de guerra civil, ou impeça o livre exercício de algum dos poderes estaduais; ou ainda na hipótese de o Estado solicitar o auxilio federal".

José Cretella Júnior, assim como Mário Masagão, usa a expressso ordem interna com o significado de ordem pública, não havendo dúvida que ambos estão se referindo à atividade policial, própria e exclusiva do Estado, o que se depreende da leitura do Tratado de Direito Administrativo, $1^{2}$ ed., Rio de Janeiro, Forense, 1966, vol. I, p. 139, que relacionando as atividades jurídicas exercidas pelo Estado destaca:

"A ordem interna do país não pode ser perturbada, sendo tal mister de competência do Estado, que tem por missão assegurar aos cidadãos a possibilidade de uma vida tranquiila, prevenindo e reprimindo os delitos."

Pelo exposto, não nos resta qualquer tipo de dúvida que, a função de polícia de trânsito, por integrar a polícia de ordem pública, configura-se em atividade jurídica do Estado, sendo-lhe, portanto, exclusiva.

7. Poder de polícia de trânsito: capacidade indelegável à pessoa jurídica de direito privado

Uma das inovações trazidas pelo Código de Trânsito Brasileiro, foi a possibilidade de atribuição de poder de polícia administrativa de trânsito aos Municípios, a partir do previsto no art. 24, incs. VI ao IX, XX e XXI, que lhes permitem fiscalizar, vistoriar, sendo que o verbo vistoriar é sinônimo de fiscalizar, tanto que o Código, no Anexo I, quando trata dos conceitos e definições, não conceitua nem define vistoria e, também, aplicar penas de polícia nas formas de advertência, multa e medidas administrativas. Atos que emanam do poder de polícia, a rigor, do art. 24, inc. VI e da definição de fiscalização, art. $4^{2}$ e Anexo I.

Porém, essas competências municipais são condicionadas, nos termos do $\S 2^{Q}$, do art. 24, que diz:

"Para exercer as competências estabelecidas neste artigo, os Municípios deverão integrar-se ao Sistema Nacional de Trânsito, conforme previsto no art. 333 deste Código".

Por sua vez, o art. 333 e $\S \S$ dispõe:

“Art. 333. O CONTRAN estabelecerá, em até 120 (cento e vinte) dias após a nomeação de seus membros, as disposições previstas nos arts. 91 e 92, que terão de ser atendidas pelos órgãos e entidades executivos de trânsito e executivos rodoviários para exercerem suas competências.

$\S 1^{2}$. Os órgãos e entidades de trânsitos já existentes terão prazo de um ano, após a edição das normas, para se adequarem às novas disposições estabelecidas pelo CONTRAN, conforme disposto neste artigo. 
$\S 2$. Os órgãos e entidades de trânsito a serem criados exercerão as competências previstas neste Código em cumprimento às exigências estabelecidas pelo CONTRAN, conforme disposto neste artigo, acompanhados pelo respectivo CETRAN, se órgão ou entidade municipal, ou CONTRAN, se órgão ou entidade estadual, do Distrito Federal ou da União, passando a integrar o Sistema Nacional de Trânsito".

Dos arts. 91 e 92, que fechavam este ciclo de remissões, foi vetado o 92 , restando o art. 91, com a seguinte redação:

"Art. 91. O CONTRAN estabelecerá as normas e regulamentos a serem adotados em todo o território nacional quando da implementação das soluções adotadas pela Engenharia de Tráfego, assim como padrões a serem praticados por todos os órgãos e entidades do Sistema Nacional de Trânsito".

Em resumo, o exercício das atribuições executivas do Município, prevista no art. 24, do Código, dependerá: dele estar integrado ao Sistema Nacional de Trânsito (art. 24, $\$ 2^{a}$ ); de atender às normas, regulamentos e padrões estabelecidos pelo CONTRAN (art. 333 e art. 91); de exercer as competências em cumprimento às exigências estabelecidas pelo CONTRAN (art. 333, § 2a); e de submeter suas atividades de trânsito ao acompanhamento e coordenação do Conselho Estadual de Trânsito - CETRAN (art. 333, $\S 2^{\circ}$ e art. 14, VIII).

Assim, a competência municipal, quase que delegada, é condicionada e supervisionada pela União, além de acompanhada e coordenada pelo Estado-membro. Esta foi a forma que ganhou a propalada municipalização do trânsito, uma panacéia, cuja inviabilidade sempre sustentamos, pelas razões alinhadas ao longo deste trabalho.

Considerando que o Município cumpra as exigências supra descritas e se habilite a fiscalizar e punir as infrações de circulação, estacionamento, parada, excesso de peso, dimensões e lotação, que lhe permite os incs. VI à VIII, do art. 24 , do novo Código de Trânsito, atos esses, todos decorrentes do poder de polícia administrativa de trânsito, mesmo assim restará submetido, aos parâmetros impostos ao poder de polícia de ordem pública.

Em gênero, Caio Tácito explica, no Poder de Polícia e seus Limites, publicado na Revista de Direito Administrativo 27/1, que:

"O poder de polícia é, em suma, o conjunto de atribuições concedidas à Administração para disciplinar e restringir em favor do interesse público adequado, direitos e liberdades individuais".

Entenda-se que os Municípios tinham, apenas, poder de polícia especial, nos exatos termos da lei, cabendo-lhes agora, obedecidas as condições acima examinadas, exercer parte do poder de polícia de trânsito, para fiscalizar e punir aquelas infrações, segundo lhes permite o Código de Trânsito.

É sempre oportuna a transcrição de excerto da matéria publicada no jornal $O$ Estado de São Paulo, de 30 de agosto de 1991, da lavra do desembargador paulista Álvaro Lazzarini, onde restou clara a obrigatoriedade do exercício do poder de polícia por órgão da Administração direta:

"Se no sistema constitucional vigente, como nos anteriores, à União compete, privativamente, legislar sobre matéria de trânsito, além de dispor sobre as suas 
infraçōes e sanções de policia de trânsito, evidentemente que a ela compete prever de quem é a competência (atribuição) para o legal exercício do Poder de Polícia, no caso, eminentemente de polícia administrativa, como é a Polícia de Trânsito, pois infração de trânsito não se confunde com infração penal, esta sim de interesse da denominada polícia judiciária (nosso Direito Administrativo da Ordem Pública, $2^{a}$ ed., Forense, p. 28).

A fiscalização de trânsito, que integra o conceito de policiamento de trânsito, bem por isso só pode ser exercida pela Administração pública enquanto poder público, e não como particular (Ruy Cirne Lima, Princípios de Direito Administrativo, 5a ed., p. 107; Jean Rivero, Direito Administrativo, 1981, p. 15; Régis Fernandes de Oliveira, Taxas de Polícia, 1980, p. 32).

Cretella Júnior salienta que o primeiro elemento de obrigatória presença é a fonte de que provém o Poder de Polícia, a existência da polícia, do policiamento: 'O Estado, ficando, pois, de lado qualquer proteção de natureza particular' (Tratado, vol. V, Polícia Administrativa, $l^{a}$ ed., p. 30)." (grifamos).

Aliás, conclusiva é a afirmação do professor Diogo de Figueiredo Moreira Neto em seu Curso de Direito Administrativo, p. 85, assim proferida:

“Em regra, cabe ao próprio Estado, em seus desdobramentos políticos e administrativos, executar as atividades de Administração pública. Tão volumosa e diversificada é, porém, essa tarefa demandada de um Estado contemporâneo, que passou a ser comum a transferência a entidades privadas dos encargos de execução, mediante instrumentos jurídicos de delegação.

A doutrina considera que certas atividades são, todavia, indelegáveis: as denominadas atividades jurídicas do Estado, que lhe são próprias e impostas como condição necessária de sua existência. As demais, delegáveis, são as chamadas atividades sociais ou impróprias, que são cometidas ao Estado na medida em que ao legislador pareçam úteis à sociedade, embora não sejam fundamentais à sua preservação.

No campo do poder de polícia, só há atividades próprias". (grifos originais).

Não existe portanto, qualquer possibilidade de delegação do poder de polícia de trânsito a empresas paraestatais ou da administração indireta. O exercício desse poder administrativo do Estado é uma de suas atividades jurídicas exclusivas e, de forma alguma, poderá ser feito por entidade que congregue capital ou interesse particular, muito menos por intermédio de seus agentes, por não restar vínculo direto e estrito com o Poder Público.

Disso não divergiu o Código de Trânsito, conforme se depreende do exame do veto ao $\S 4^{\circ}$, do art. $1^{\circ}$, quando dizia:

"A exigência de que o Sistema Nacional de Trânsito seja composto por entidades dotadas de personalidade jurídica própria constitui uma limitação, que, além de afrontar o disposto no art. $61, \S 1^{\circ}$, inc. II, alínea e, da Constituição, restringe, em demasia, o poder de conformação da União e dos Estados-membros na estruturação e organização desse serviço".

Personalidade jurídica própria, para exercer fiscalização, somente poderia ser a de direito público, mas ao falar em administração indireta a regra tornou-se intrinsecamente conflitante, obrigando, por essa razão, ao veto. 
Se o poder de polícia de trânsito e suas exteriorizações, a fiscalização e a punição, pelas razões enunciadas e à evidência são próprias do poder público e nos limites da lei, qualquer tentativa de delegá-lo a paraestatais só poderá ser considerada ilegal, sujeitando-se o dirigente do órgão público à responsabilidade penal, civil e administrativa.

Qualquer ação estatal, sem o correspondente calço legal ou que exceda ao âmbito demarcado pela lei, é injurídica; expõe-se à anulação e torna seu autor passível de responsabilidade disciplinar, civil e criminal, conforme já o dissemos em outra ocasião, em nosso Direito Administrativo, S. Paulo, Saraiva, 1989, p. 6.

Assim, o exercício do poder de polícia de trânsito pelos Municípios terá de ser feito por seus órgãos ou por suas entidades, na forma de fundações ou autarquias, todos pessoas jurídicas de direito público, submetidas aos princípios constitucionais da legalidade, impessoalidade, moralidade e publicidade, dentre outros.

Cumpre-nos dizer, também, que além do poder de polícia ser indiscutivelmente da essência do Estado, no caso do trânsito ressalta, dentre os princípios da administração, o da moralidade. Todos sabemos e os condutores já sentiram na pele o que significa a indústria da multa, instalada pelo Poder Público em alguns Municípios, como maneira de buscar recursos para os seus cofres. Imagine-se a mesma indústria na mão de particulares com a finalidade de auferir lucro.

Em 03 de dezembro do corrente, o Jornal da Tarde veiculou matéria sob o título: INDÚSTRIA DE MULTA NA MIRA DO MP, onde o vereador Arselino Tatio estaria representando ao Ministério Público do Estado contra a Companhia de Engenharia de Tráfego (CET), com o objetivo de se apurar abuso em aplicação de multas.

$O$ vereador afiança que:

"É estarrecedor o aumento no número das multas. Isso virou uma indústria".

$\mathrm{Na}$ mesma matéria, o presidente do Sindicato dos Trabalhadores do Sistema Viário denuncia a pressão que os empregados da CET, que são carinhosamente chamados de "marronzinhos", estão sofrendo, no sentido de que multem pelo menos 40 (quarenta) veículos por dia.

Por esse motivo específico, o próprio vereador Arselino Tatto arremata, concluindo que:

"O aumento na aplicação de multas visa somente arrecadar mais dinheiro para cobrir o rombo no caixa da Prefeitura".

Não podemos e nem devemos admitir que a própria Comunidade sinta e sofra, na pele, a ânsia dessa indústria de multa, que somente tem por objetivo, $o$ arrecadar e, por via de consequiência, suprir o orçamento da Secretaria Municipal de Finanças que repassa, na proporção prevista, parte da arrecadação para a CET que é, como já nos manifestamos em outros estudos, uma empresa de economia mista, na qual o Município de São Paulo está associado a particulares.

Nesse sentido vem a lição do saudoso professor Hely Lopes Meirelles, publicada no Direito Administrativo Brasileiro, 17 $\mathrm{a}$ ed., atualizada por Eurico de Andrade Azevedo, Délcio Balestero Aleixo e José Emmanuel Burle Filho, Malheiros, 1992, p. 84, ao descrever a moralidade administrativa:

"E, ao atuar, não poderá desprezar o elemento ético de sua conduta. Assim, 
não terá que decidir somente entre o legal e o ilegal, o justo e o injusto, o conveniente $e o$ inconveniente, o oportuno $e$ o inoportuno, mas também entre o honesto e o desonesto. Por considerações de Direito e de moral, o ato administrativo não terá que obedecer somente à lei jurídica, mas também à lei ética da própria instituição, porque nem tudo que é legal é honesto;..." (grifamos).

Claro está que permitir à administração indireta, às sociedades anônimas, às pessoas jurídicas de direito privado, enfim, aos particulares, ainda que parcialmente, utilizarem-se do poder de polícia de trânsito, que é poder de império do Estado, cuja sanção é unilateral, externa e interventiva, para aplicar e arrecadar multas que reverterão em lucros ou dividendos a esses mesmos particulares, não pode ser legal e jamais será considerado honesto, moral e ético. Pelo contrário, tratar-se-á de autêntica aberração contra a qual a Sociedade precisa ficar alerta, tendo em vista que interessados nesse abuso não faltam.

Tanto que alguns juristas têm elaborado pareceres no sentido de que o poder de polícia, em casos específicos e sobre áreas bem definidas, que estariam no âmbito do poder de polícia administrativa especial, poderia ser delegado a empresas paraestatais o que, no nosso entender, configura uma absoluta impropriedade, por minar os fundamentos do Poder Público.

Essa linha de pensamento só pode pretender que se autorize a delegação do poder de polícia em matéria de polícia administrativa especial, ou como diz Diogo de Figueiredo Moreira Neto, nas atividades sociais; não poderia ser estendida às atividades jurídicas, de tutela de direitos, que são próprias do Estado, pois só ele, "de per si", é capaz de garanti-las.

Ainda que acatássemos a tese da delegabilidade do poder de polícia especial, de forma alguma poderia ela ser aplicada à fiscalização de trânsito que, como já demonstramos, é matéria de polícia administrativa geral, posto que referente à ordem pública, necessariamente, atividade jurídica do Estado.

Por certo, o Estado que delegasse aos particulares tão essenciais funções, ou ainda, que os deixasse organizar tais serviços como bem lhes parecesse, não teria mais razão de existir, confessada, como estaria, sua absoluta incapacidade para o cumprimento das atribuições que the são exclusivas.

De forma geral, o Poder Judiciário tem entendido que todo poder de polícia, seja ele de polícia administrativa geral ou especial, é indelegável a particular, ainda que empresa paraestatal.

A propósito vem a Apelação no 275.612, da Comarca de Piracicaba, Sexta Câmara do Primeiro Tribunal de Alçada Civil (JTACSP, Saraiva, 1972, p. 100/102), em cujo aresto ficou consignado:

“Mas, na sua defesa, a requerida argumenta, com vantagem, que inexistiu propriamente recusa à participação nos atos de fiscalização. Ocorre que a Prefeitura firmara contrato com empresa de consultoria e assessoria, com a finalidade de aumentar a arrecadaçāo do ISS; os prepostos dessa empresa, contudo, ao invés de se dedicarem a trabalhos de assessoria, passaram a executar tarefas que por definição legal são atribuídas com exclusividade a funcionários, ou agentes fiscais, valendo-se, para assim proceder, de um, credenciamento fornecido pela Prefeitura."' (grifamos). 
Para arrematar, reafirmamos que poder de polícia não pode ir para as mãos de particulares, mesmo quando organizados de maneira empresarial e associados ao Poder Público, não havendo para isso artifício legal, em face de sua flagrante inconstitucionalidade.

\section{Vinculação da receita proveniente das multas de trânsito}

Regra da maior importância constitui o art. 320 do Código de Trânsito Brasileiro:

“A receita arrecadada com a cobrança das multas de trânsito será aplicada, exclusivamente, em sinalização, engenharia de tráfego, de campo, policiamento, fiscalização e educação de trânsito.

Parágrafo único. O percentual de 5\% (cinco por cento) do valor das multas arrecadadas será depositado, mensalmente, na conta de fundo de âmbito nacional destinado à segurança e educação de trânsito".

Trata-se da vinculação do total da receita proveniente das multas de trânsito com as atividades ligadas diretamente ao trânsito, impedindo seu remanejamento para outras áreas de interesse do Governo, ato tão a gosto de nossos governantes.

Portanto, a partir da entrada em vigor do novo Código, o recurso oriundo de multa de trânsito haverá de ser revertido, exclusivamente, em benefício do trânsito.

À exceção do fundo nacional de segurança e educação de trânsito, que tem seu percentual fixado $(5 \%)$, as demais atividades de trânsito: sinalização, engenharia, policiamento, fiscalização e educação terão seus percentuais determinados segundo a legislação de cada ente estatal. Note-se que a todas essas atividades deverão ser destinadas recursos e não a apenas algumas, em detrimento das outras.

Em relação ao policiamento ostensivo de trânsito ocorre situação peculiar porque as multas de circulação, parada e estacionamento, excesso de peso, dimensões e lotação aplicadas pela Polícia Militar, no âmbito das vias municipais, reverterão aos cofres do Município, pois a Corporação não tem como arrecadá-las, embora tenha direito a que parte da receita seja destinada ao policiamento, na forma de repasse. $\mathrm{Na}$ verdade, esse direito é do Estado-membro, ao qual pertence a Polícia Militar.

Daí nosso entendimento de que as regras para o respectivo repasse deverão ser feitas por intermédio de lei estadual, disciplinando a matéria de maneira uniforme em todo o Estado, não vislumbrando a invasão de competência, haja vista que a lei ordinária federal, que é o instrumento que exteriorizou o novo Código de Trânsito Brasileiro, obrigou que parte da arrecadação terá de ser repassada e aplicada no policiamento.

Por esses motivos, constatamos que a própria vinculação da receita das multas, com o policiamento ostensivo de trânsito, já veio definida e está expressa no art. 320 , do novo Código e abrange toda e qualquer multa, sem que haja distinção com referência ao tipo ou quem seja a autoridade competente que a aplicou.

Ora, quem executa o serviço de policiamento é o Estado-membro, portanto, ele é quem tem de conhecer sobre os reais custos do serviço prestado. Em sendo direito do Estado-membro, não resta ao Município qualquer competência legislativa neste 
particular, estando assim suplantada pela do Estado no que concerne, especificamente, ao tal custo do serviço.

Deixar a cada Município fixar o percentual de recursos a ser repassado para o policiamento, competência do Estado-membro, não nos parece a melhor alternativa, em razão da quantidade e da disparidade de intenções dos Municípios.

\section{Policiamento ostensivo de trânsito e fiscalização de trânsito}

Policiamento é exercício regular do poder de polícia, que compete à Administração Pública, não existindo propriamente diferenças entre policiamento e fiscalização. A fiscalização de trânsito é apenas um dos modos de atuação do agente público quando põe em prática o poder de policia. Não é, como se possa interpretar, um outro poder de polícia.

Com peculiar clareza, o professor Diogo de Figueiredo Moreira Neto (obra citada, p. 295) explica que:

"O poder de polícia atua de quatro modos: pela ordem de polícia, pelo consentimento de polícia, pela fiscalização de polícia e pela sanção de polícia” (grifos originais).

E continua mais adiante (obra citada, p. 297):

"Segue-se a fiscalização de polícia. Ela se fará tanto para a verificação do cumprimento das ordens de polícia quanto para observar se não estão ocorrendo abusos nas utilizaçōes de bens e nas atividades privadas que receberam consentimentos de polícia. Sua utilidade é dupla: primeiramente, realiza a prevenção das infrações pela observaçāo do cumprimento, pelos administrados, das ordens e dos consentimentos de polícia; em segundo lugar, prepara a repressão das infrações pela constatação formal dos atos infrigentes" (grifos originais).

No trabalho, A Segurança Pública na Constituição, Revista de Informação Legislativa, $\mathrm{n}^{\mathrm{Q}}$ 109, Brasília, Senado Federal, janeiro/março 1991, p. 147, o professor e procurador do Estado do Rio de Janeiro Diogo de Figueiredo Moreira Neto foi mais fundo na questão, ao afirmar que:

“A fiscalização de polícia é uma forma ordinária e inafastável de atuação administrativa, através da qual se verifica o cumprimento da ordem de polícia ou a regularidade da atividade já consentida pòr uma licença ou unia autorização. $A$ fiscalização pode ser ex-ofício ou provocada. No caso específico da atuação da polícia de preservação da ordem pública, é que toma o nome de policiamento" (grifos originais).

O Código de Trânsito, em seu Anexo-I, cuja aplicação advém do art. 4ª, apresentou definições distintas para fiscalização:

"ato de controlar o cumprimento das normas estabelecidas na legislação de trânsito, através do poder de polícia administrativa de trânsito, no âmbito de circunscrição dos órgãos e entidades executivos de trânsito e de acordo com as competências definidas neste Código" (grifamos).

Para policiamento ostensivo de trânsito:

"função exercida pelas Polícias Militares com o objetivo de prevenir e reprimir 
atos relacionados com a segurança püblica e de garantir obediência às normas relativas à segurança de trânsito, assegurando a livre circulação e evitando acidentes" (grifamos).

Note-se que, para o Código, fiscalizar é controlar, pois este foi o verbo central da definição. Verbo, todos nós sabemos, exprime ação ou estado das coisas. Por sua vez, a definição de policiamento trouxe, em lugar do verbo, o substantivo função.

Ora. mas como se processa a ação do policiamento? Onde está o verbo que exprimiria essa ação?

Está evidentemente implícito que é o verbo fiscalizar ou controlar. $\mathrm{Na}$ verdade faltou, ao legislador, precisão na construção gramatical o que não impede uma exegese correta, a partir da doutrina, da jurisprudência e, principalmente, da comparação com os demais diplomas legais, conforme veremos mais adiante.

Combinando a definição de fiscalização com outros dispositivos do Código (art. 21 , VIII, IX e XIII; art. 24, VI, VIII, IX e XX), verificamos que a intenção do legislador foi a de limitar a aplicação do poder de polícia. Nesses casos, a fiscalização de trânsito e a conseqüente sanção, somente se aplicariam às infrações de circulação, estacionamento, parada, excesso de peso, dimensões, lotação, emissão de poluentes e ruídos, isso se considerarmos fiscalização nas vias públicas (art. 2ª). Porém, existe, também, outro campo de fiscalização de trânsito, relativo a processos de formação, habilitação, aperfeiçoamento e reciclagem de condutores (art. 22, II), bem como as vistorias e inspeções para emplacar e licenciar veículos, todas estas feitas em repartições públicas, por instrumentos burocráticos.

Num plano mais amplo, está o policiamento ostensivo de trânsito, atividade para qual o legislador fixou, no Código, quatro objetivos a saber:

$\left.1^{\circ}\right)$ prevenir e reprimir atos relacionados com a segurança pública; $\left.2^{\mathfrak{e}}\right)$ garantir a obediência às normas relativas à segurança de trânsito; 3o) assegurar a livre circulação e $4^{\mathfrak{l}}$ ) evitar acidentes.

A consecusão desses objetivos inclui obrigatoriamente, a fiscalização de trânsito nas vias públicas retro descrita, agregada a outros controles, como: o estado de conservação do veículo e seus equipamentos obrigatórios; as condições legais e físicas do condutor; a revista no interior do veículo; a busca pessoal em seus ocupantes, se for o caso e o envolvimento em acidentes ou ilícitos penais. Enfim, um aglomerado de atos interligados que não podem sofrer solução de continuidade, e por força disso, a boa doutrina manda não dividir.

Portanto, o policiamento ostensivo de trânsito inclui a fiscalização das infrações de trânsito praticadas nas vias públicas e demais atos de polícia relativos ao trânsito, componentes do conjunto de medidas destinado, diretamente, a manter integra a ordem pública.

A fiscalização que é tratada pelo art. 23 , inc. III, e para a qual teria de ser celebrado convênio, seguramente, não abrange a realizada nas vias públicas, pois essa é inerente ao policiamento ostensivo de trânsito, referindo-se ao outro tipo de fiscalização voltada, especificamente, para aspectos do trânsito que afetem, indiretamente, a ordem pública, conforme encontramos no art. 22, inc. II, do novo Código.

Em resumo, fica claro que o espírito do novo Código de Trânsito Brasileiro, 
nessa matéria é: quem é competente para policiamento ostensivo de trânsito atua de forma ampla, enquanto quem é competente para a fiscalização atua, especificamente, em determinada parte da atividade, segundo estabelece o próprio Código.

\section{Competência da Polícia Militar para exercer o policiamento ostensivo de trânsito}

Quando se fala em competência, vem logo à mente a lição do festejado professor Caio Tácito, O Abuso do Poder Administrativo no Brasil - conceito e remédios, co-edição do Departamento Administrativo do Serviço Público e Instituto Brasileiro de Ciências Administrativas, Rio de Janeiro, 1959, p. 27, assim oferecida:

"A primeira condiçāo de legalidade é a competência do agente. Não há, em direito administrativo, competência geral ou universal: a lei preceitua, em relação a cada funçāo pública, a forma e o momento do exercício da atribuição do cargo. Não é competente quem quer, mas quem pode, segundo a norma de direito. A competência é, sempre, um elemento vinculado, objetivamente fixado pelo legislador".

Ainda, nesse particular, cabe trazer à colação, a afirmativa segura do saudoso professor Teófilo Cavalcanti Filho, estampada no Boletim do Interior, vol. 29, p. 31, publicação da Fundação Prefeito Faria Lima - CEPAM, manifestada nestes termos:

"E quando se trata de matéria de competência, não se ignora, tem-se que levar sempre em conta o que a norma legal dispõe".

Pois bem! Vejamos então o que diz a lei sobre a competência das Polícias Militares, começando pelo art. 144, "caput", inc. V e $\$ 5^{\circ}$, da Carta Política federal:

"Art. 144. A segurança pública, dever do Estado, direito e responsabilidade de todos, é exercida para a preservação da ordem pública e da incolumidade das pessoas e do patrimônio, através dos seguintes órgãos:

V...

$\mathrm{V}$ - polícias militares e corpos de bombeiros militares.

$\S 5^{\varrho}$ Às polícias militares cabem a polícia ostensiva e a preservação da ordem pública;...".

Agora, no plano infraconstitucional, o Decreto-lei federal $\mathrm{n}^{\circ}$ 667, de 02 de julho de 1969 , com as alterações efetuadas pelos Decretos-leis federais de $\mathrm{n}^{2} 1.406$, de 24 de junho de 1975 e 2010, de 12 de janeiro de 1983, que reorganizou as Polícias Militares, em seu art. 3o, letra "a", assegura-lhes o policiamento geral:

"Art. 32. Instituídas para a manutenção da ordem pública e segurança interna nos Estados, nos Territórios e no Distrito Federal, compete às Polícias Militares, no âmbito de suas respectivas jurisdições:

a executar com exclusividade, ressalvadas as missões peculiares das Forças Armadas, o policiamento ostensivo, fardado, planejado pela autoridade competente, afim de assegurar o cumprimento da lei, a manutenção da ordem pública $e$ o exercício dos poderes constituidos;" (grifamos).

$\mathrm{Na}$ seqüência, o seu Regulamento, que é o Decreto federal $\mathrm{n}^{2} 88.777$, de 30 de 
setembro de 1983, especifica os tipos de policiamento ostensivo existentes, entre eles o de trânsito e rodoviário:

“Art. 2". Para efeito do Decreto-lei $n^{\circ}$ 667, de 2 de julho de 1969, ... são estabelecidos os seguintes conceitos:

21 - Ordem Pública: conjunto de regras formais, que emanam do ordenamento jurídico da Nação, tendo por escopo regular as relações sociais de todos os níveis, do interesse público, estabelecendo um clima de convivência harmoniosa e pacífica, fiscalizado pelo Poder de Polícia, e constituindo uma situaçāo ou condição que conduza ao bem comum;

...

27 - Policiamento Ostensivo: ação policial, exclusiva das Policias Militares, em cujo emprego o homem ou a fração de tropa engajados sejam identificados de relance, quer pela farda, quer pelo equipamento, ou viatura, objetivando a manutenção da ordem pública.

São tipos desse policiamento, a cargo das Polícias Militares, ressalvadas as missões peculiares das Forças Armadas, os seguintes:

- de trânsito;

- rodoviário e ferroviário, nas estradas estaduais;..." (grifamos).

No Estado de São Paulo, a Lei estadual n 616, de 17 de dezembro de 1974, veio reafirmar, como não poderia deixar de fazer, a legislação federal, relativa ao policiamento de trânsito da seguinte forma:

“Art. 3". Entende-se por policiamento ostensivo a ação policial em cujo emprego o homem ou a fração de tropa engajados sejam identificados de imediato quer pela farda, quer pelo equipamento, quer pelo armamento ou viatura.

Parágrafo único. O policiamento ostensivo será executado no território estadual nas seguintes atividades de segurança:

2. trânsito;

7. rodoviário, nas rodovias estaduais e municipais;".

Convém observar que, o Código Nacional de Trânsito, que era anterior a toda essa legislação, não mencionava o policiamento de trânsito e, consequientemente, nem as Polícias Militares.

Já ao contrário, o novo Código de Trânsito Brasileiro prevê o policiamento ostensivo de trânsito, como incumbência das Polícias Militares e as inclui no Sistema Nacional de Trânsito, nos termos do seu art. 7울

"Art. 7. Compõem o Sistema Nacional de Trânsito os seguintes órgãos e entidades:

VI - as Policias Militares dos Estados e do Distrito Federal;"

Cumpre-nos, portanto, examinar a compatibilidade entre o Código de Trânsito Brasileiro e as leis anteriores, cujo objeto são as Polícias Militares, verificando o aspecto específico do policiamento de trânsito urbano e rodoviário. 
De início, anote-se que, não existiu revogação expressa e nem há qualquer elemento que nos permita concluir que tenha havido revogação tácita, por incompatibilidade entre os diplomas analisados. Ao contrário, trata-se do encontro entre norma geral sancionada posteriormente e as normas especiais.

A norma geral sendo complementada, sem resvalar para a ilegalidade e respeitando-se a sua limitação, imposta pela norma especial, é fenômeno que está disciplinado pela Lei de Introdução ao Código Civil, no § 2으, do art. $2^{2}$ :

“Art. 20....

...

$\S 2^{\circ}$ A lei nova, que estabeleça disposições gerais ou especiais a par das já existentes, não revoga nem modifica a lei anterior" (grifamos).

O Código de Trânsito Brasileiro, pela sua natureza, é lei nova de caráter geral sobre trânsito, abordando-o em todos os seus aspectos, enquanto os dispositivos legais, que versam sobre as competências das Polícias Militares, quando tratam de trânsito, fazem-no de forma especial, vez que se destinam a disciplinar, concomitantemente, outros assuntos. Por isso, ao abordar sobre disposições gerais ou adentrando às disposições especiais, ao lado das já existentes no Ordenamento Jurídico, a lei posterior não revoga a lei anterior, naquilo que é de sua especificidade.

Conforme ensina o professor Carlos Maximiliano, em Hermenêntica e Aplicação do Direito, p. 146:

"As antinomias ou incompatibilidades implícitas não se presumem; devem ser inequivocas e demonstradas."

A hipótese aqui analisada não demonstra qualquer antinomia entre a regra geral, que é no caso o Código de Trânsito Brasileiro, nem as regras especiais, que são o Decreto-lei $n^{9} 667 / 69$; o Decreto $n^{2} 88.777 / 83$ e a Lei $n^{2} 616 / 74$, até porque todas elas contemplam, como figura jurídica o policiamento ostensivo de trânsito.

Assim, a lei posterior em matéria de competência das Policias Militares para exercerem o policiamento de trânsito confirmou, simplesmente, toda a legislação pré-existente.

\section{Abordagem de veículo e registro de acidente de trânsito}

A abordagem de veículos, precedida de ordem de parada, com a finalidade de fiscalizar as condições físicas e documentais de condutores e dos próprios veículos, continua sendo atribuição exclusiva da Polícia, seja das Polícias Militares (art. 4q, Anexo-I, policiamento ostensivo de trânsito) ou da Polícia Rodoviária Federal (art. 20, II). Inclui-se aqui a realização de teste de dosagem de alcoolemia, cuja obrigatoriedade é de duvidosa constitucionalidade e a perícia de substância entorpecente ou que determine dependência física ou psíquica (art. 269, IX).

$\mathrm{O}$ mesmo se aplica à busca pessoal nos ocupantes e no próprio veículo, ato vinculado ao Decreto-lei federal $\mathrm{n}^{\mathfrak{Q}} 3.689$, de 3 de outubro de 1941, Código de Processo Penal, art. 244 e em consonância com o restante do Ordenamento Jurídico brasileiro.

Os bloqueios nas vias públicas, usual tática usada pela Polícia, permanece 
incluída no rol de suas capacidades funcionais exclusivas, a rigor da infração capitulada no art. 210, do novo Código:

"Transpor, sem autorização, bloqueio viário policial: infração gravíssima;".

O Código de Trânsito Brasileiro pouco inovou neste aspecto, permitindo, a abordagem de veículo por agente público municipal competente, apenas e tão-somente, no tocante à fiscalização de excesso de peso e dimensões (Art. 24, III), as quais, certamente, exijam tal providência. No mais, encontrando ou suspeitando de outra infração, administrativa ou penal que requeira abordagem, terá de valer-se da ação policial.

Quanto ao registro de acidentes e infrações penais de trânsito também continua sendo próprio das atribuições da Polícia. Nesse ponto, consideramos compatível com o novo Código e por isso, está em vigor, a Lei federal no 5.970 , de 11 de dezembro de 1973, que disciplina o registro de acidentes de trânsito. Daí o disposto no art. 176, inc. V, do Código de Trânsito:

"Art. 176. Deixar o condutor envolvido em acidente com vítima:

V - de identificar-se ao policial e de lhe prestar informações necessárias à confecção do boletim de ocorrência: infração - gravíssima".

Evidente que esta pessoa estaria, ainda, em tese, incorrendo no crime de desobediência, por não ter atendido à determinação legal de funcionário público, conforme tipifica o art. 330 do Código Penal Brasileiro.

\section{2. Órgãos de trânsito}

O Código de Trânsito Brasileiro prevê quatro tipos de órgãos: $1^{\circ}$ ) os normativos - consultivos e coordenadores; $2^{2}$ ) os executivos de trânsito e rodoviários; $3^{\circ}$ ) os policiais e $4^{2}$ ) os recursais. Esse conjunto de órgãos, preenchidas as condições legais, formam o Sistema Nacional de Trânsito.

Os órgãos normativos que são consultivos e de coordenação, foram perfeitamente definidos pelo Código, como é o caso do Conselho Nacional de Trânsito CONTRAN (art. $7^{0}, I$ e art. 10), dos Conselhos Estaduais de Trânsito CETRAN e do Conselho de Trânsito do Distrito Federal - CONTRANDIFE (art. 7, II e art. 14). O mesmo ocorreu, em relação aos órgãos policiais, prevendo a Polícia Rodoviária Federal (art. $7^{\circ}, \mathrm{V}$ e art. 20) e as Policias Militares (art. $7^{\circ}, \mathrm{VI}$, art. 23 e art. 4ㅁ, Aneto-I, policiamento ostensivo de trânsito). Os órgãos recursais ficaram definidos na forma de Juntas Administrativas de Recursos de Infrações - JARI.

O que o Código não fixou foram os órgãos executivos de trânsito e executivos rodoviários. Para esses, o legislador deixou à União e às Unidades Federativas, a tarefa de organizá-los, quando dispõe no art. $8^{\circ}$ que:

“Os Estados, o Distrito Federal e os Municípios organizarão os respectivos órgãos e entidades executivos de trânsito e executivos rodoviários, estabelecendo os limites circunscricionais de suas atuações." (grifamos).

No caso da União cumpre observar o art. $7^{2}$, incisos III e IV: 
“Art. 7". Compõem o Sistema Nacional de Trânsito os seguintes órgãos e entidades:

III - os órgãos e entidades executivos de trânsito da União, dos Estados, do Distrito Federal e dos Municípios;

IV - os órgãos e entidades executivos rodoviários da União, dos Estados, do Distrito Federal e dos Municípios;"

Note-se que podem ser vários órgãos executivos, pois o rol de atribuições que lhes cabe (art. 19, art. 21 e art. 24) é extenso, assim nada impede a divisão dessas atribuições, desde que fixados os limites de atuação de cada órgão observando o disciplinamento regulamentar.

Tais órgãos podem pertencer à Administração direta ou mesmo indireta, no caso destes, conforme explicamos longamente. A ressalva seria a impossibilidade de atribuir-lhes poder de polícia para a fiscalização do trânsito.

A distribuição das atribuições pelos órgãos executivos de trânsito, poderá ser feita, inclusive, por decreto, de vez que configura organização interna do Poder Executivo. Bem por isso, a União já o fez, em relação ao Departamento Nacional de Trânsito - DENATRAN, por intermédio do Decreto federal $n^{2} 2.351$, de 17 de outubro de 1997.

A extensão de atribuições executivas de trânsito, no âmbito da mesma esfera de poder é possível também à Policia Rodoviária Federal e às Polícias Militares, órgãos da Administração Direta, recomendando-se apenas, que tais atribuições sejam coerentes com as atividades de patrulhamento e policiamento ostensivo de trânsito exercidas, respectivamente, por essas Corporações.

\section{A interrupção da via pública e o direito de reunião}

Um dos dispositivos do novo Código de Trânsito Brasileiro que deverá causar polêmica é o art. 95 que diz:

"Nenhuma obra ou evento que possa perturbar ou interromper a livre circulação de veículos e pedestres, ou colocar em risco sua segurança, será iniciado sem permissão prévia do órgão ou entidade de trânsito com circunscrição sobre a via". (grifamos).

Parece-nos que o legislador misturou coisas distintas o que, a nosso ver, não deveria ter ocorrido. Quanto às obras não há problema, pois enquadram-se no interesse do Município e estão sob a égide da legislação local. Os eventos, porém, podem dizer respeito às manifestações públicas inseridas no direito de reunião, consagrado pelo art. 5, inc. XVI, da Constituição da República; logo, trata-se de matéria da União e dos Estados, nas suas competências de preservação da ordem pública.

Assim, no tocante aos eventos, consideramos prejudicada a competência municipal, aventada que está no art. 24, inc. IX, do Código de Trânsito.

Aliás, para se exercer o direito de reunião não é preciso permissão, bastando 
prévio aviso à autoridade competente, conforme alerta o professor José Afonso da Silva (Curso de Direito Constitucional Positivo, p. 238 e 239):

"Agora apenas cabe um aviso, mero aviso, à autoridade que terá o dever de ofício de garantir a realização da reunião". (grifo original).

O Corpo Técnico-jurídico da Fundação Prefeito Faria Lima - CEPAM, manifestou-se no mesmo sentido em obra citada, à p. 36, que o direito de reunião:

"Pode ser exercido, hoje, independentemente de autorização das autoridades, sendo exigido apenas o aviso prévio para que possam ser tomadas todas as precauções que dele dependam (por exemplo, providências para que seja garantida a segurança dos participantes)". (grifamos).

E continua, arrematando que:

"Importante frisar que não basta seja a reunião levada a efeito sem o uso de armas; deverá também ter fins pacíficos, de modo a não perturbar a ordem pública nem ferir o interesse coletivo". (grifamos).

Sendo matéria de ordem pública e tendo por objetivos a livre circulação e a segurança de veículos e pedestres, expressos pelo art. 95, do novo Código, a autoridade a ser avisada será órgão da Polícia Militar, competente para a execução do policiamento ostensivo de trânsito no local do evento. Afinal, esses estão entre os objetivos contidos na definição de policiamento ostensivo de trânsito (art. $4^{\circ}$, Anexo I do Código). 